daily amounts of proteins $(700 \mathrm{~g} /$ day $)$, amino-acids, vitamins, minerals being equivalent. Measurements of milk production were carried out on days $1,5,9,13,17$ and 21 . $\mathrm{O}_{2}$ consumption and $\mathrm{CO}_{2}$ production were measured the other days of the lactation period. Energy, protein and fat deposition (or mobilization) in maternal tissues, energy and protein in milk and heat production of the sow were measured. Results concern the first 4 replicates.

Sows on treatment $\mathrm{B}$ had a higher body weight loss $(22.6$ vs $10.5 \mathrm{~kg})$, the milk production beeing equivalent in the 2 groups. However, milk composition was slightly different : 18.24 and 19.14 p. 100 dry matter, 11.83 and $12.68 \mathrm{Cal} / \mathrm{g} .7 .12$ and 7.59 p. 100 lipids for groups $\mathrm{H}$ and $\mathrm{B}$, respectively. Heat production was higher in group $\mathrm{H}$ (7.8vs 7.1 Mcal/day), but total energy retention was significantly lower for group B (2.7 vs $6.7 \mathrm{Mcal} /$ day $)$. Since energy produced in milk was equivalent for both treatments $(7.2$ and 6.7 Mcal/day), sows of group B mobilized higher amounts of body reserves (4.0 vs $0.6 \mathrm{Mcal} /$ day). This mobilization was larger during the second part of lactation : 0.2 and $3.0,1.6$ and $4.9 \mathrm{Mcal} /$ day from days 5 to 12 and 13 to 21 , respectively. Protein supplies $(700 \mathrm{~g} /$ day $)$ met the requirements for lactation. Consequently, the mobilization of body reserves only concerned the fat reserves of the sow (60 and $440 \mathrm{~g}$ lipids/day for groups $\mathrm{H}$ and $B$ respectively). However, this loss of lipids was lower than the body weight loss of the animals. The whole experiment (10 replicates) will provide more accurate information about the composition of the weight loss (dissection and chemical analysis of the carcass) and precise estimates of the energy requirements of the lactating sow (maintenance requirements, efficiency of food and body reserves for milk production).

\title{
Comparative utilization of wheat and rye by the bacon pig during the growing-finishing period
}

\author{
O. LAVOREL, F. GROSJEAN \\ I.T.C.F., 8, avenue du Président-Wilson, 75116 Paris \\ France
}

Two experimental diets containing either wheat or rye and soyabean meal, with the same lysine/DE balance $(2.7 \mathrm{~g}$ per $1000 \mathrm{Kcal} \mathrm{DE})$ were compared in this trial. Both diets were fed restricted to Large White pigs between 27 and $101 \mathrm{~kg}$ live weight. The trial was made on 84 animals (42 per diet).

Rye was well accepted by the pigs.

The feed restriction scheme used theoretically supplied the same amounts of DE and lysine in the two diets and should lead to the same growth rate with the two cereals.

Only a slight difference was observed in favour of wheat $(2 \mathrm{p}$. 100). The feed conversion ratio was 5 p. 100 higher with rye as compared to wheat. Moreover, rye led to a 0.75 point reduction in the carcass yield.

It may be concluded that rye can be used without any problem as sole cereal in fattening pig diets. A less severe feed restriction should be adopted than with wheat in order to counterbalance its lower energy concentration (about $3650 \mathrm{Kcal} \mathrm{DE} / \mathrm{kg}$ D.M.). This leads to the same growth rate, but the feed conversion ratio is deteriorated by about 5 p. 100.

\section{Prediction of the energy value of oats from cell wall content}

\author{
J.M. PEREZ, D. BOURDON \\ I.N.R.A., Station de Recherches sur l'Elevage des Porcs, Saint-Gilles, \\ 35590 L'Hermitage \\ France
}

A digestibility experiment was made with 12 Large White castrated male pigs to estimate the feeding value of different types of oats and to define more accurately the effect of changes in their chemical composition on the energy value. The animals with a 